\title{
DOKUDAH - DOKUMENTARNI FILM \\ KAO EDUKACIJA U PREDAHU U KNJIŽNICI FILOZOFSKOG FAKULTETA U ZAGREBU
}

\author{
DOKUDAH - A DOCUMENTARY FILM AS EDUCATION \\ DURNIG BREAK TIME IN THE LIBRARY OF THE FACULTY \\ OF HUMANITIES AND SOCIAL SCIENCES IN ZAGREB
}

\section{Elvira Gotal}

Filozofski fakultet, Sveučilište u Zagrebu

egotal@ffzg.hr

UDK / UDC 025.7:791(497.5 Zagreb)

Stručni rad / Professional paper

Primljeno / Received: 2. 11. 2018.

Prihvaćeno / Accepted: 7.1.2019.

\section{Sažetak}

Cilj. Cilj je ovog rada opisati i obrazložiti važnost programa Dokudah koji se provodi u Knjižnici Filozofskog fakulteta u Zagrebu. Program se sastoji od projekcija dokumentarnih filmova i popratne diskusije. Istovremeno, obrazlaže se važnost dokumentarnog filma kao specifičnog oblika audiovizualne građe koji ima sve veću edukacijsku ulogu. Program promiče dokumentarni izričaj, suradnju, kritičko mišljenje i aktivizam, uz to upućuje na važnost audiovizualne građe i njezine zbirke u Knjižnici Filozofskog fakulteta te audiovizualne baštine i kulture općenito.

Pristup. U ovom će se radu obrazložiti teorijska i praktična pozadina programa Dokudah, njegov razvoj i edukativna svrha. Sam termin proizlazi iz akronima sintagme dokumentarni predah i odnosi se na dokumentarni film kao predah u okruženju u kojem prevladavaju knjige te se u tom smislu film javlja kao odmak od čitanja, no istovremeno educira, obrazuje i aktivira pojedince.

Rezultati. Program je nastao 2015. godine i kontinuirano se razvijao s povremenim stankama.

Vjesnik bibliotekara Hrvatske 61, 2(2018), 287-303

ISSN 0507-1925

(C) VBH 2018. 
Rezultati su provođenog programa uspostavljena suradnja sa studentskim klubovima, nakon toga suradnja s nezavisnim produkcijskim kućama, ispostava i projekcije filmova, aktivno gledanje i poticajna diskusija te, na kraju, osmišljavanje bloga.

Ograničenja. Važna su točka u programu autorska prava. Zbog financijske ograničenosti javne projekcije nisu bile moguće i u tom se smislu čitav Dokudah zasniva na suradnji kao osnovnom načinu izvedbe i provedbe programa. U naknadnim varijantama poput programa Dokudah i zelene knjižnice varijante se mijenjaju i prilagođavaju ovisno o uvjetima autorskog prava.

Praktična primjena. Program Dokudaha ističe važnu ulogu dokumentarnog filma na svim razinama obrazovanja. Zbog rascjepkanosti svojih obaveza na studiju studenti mogu takvim dodatnim programom kvalitetno ispuniti vrijeme između predavanja. Isto tako može se uključiti u koncept otvorene nastave te se provoditi kontinuirano s naznačenim ishodima.

Društveni značaj. Ostvarivanjem kontakata s vanjskim suradnicima omogućuje se aktivnije uključivanje u zajednicu. U tom smislu osmišljen je i blog kako bi na jednom mjestu okupio korisne informacije na temelju kojih bi se pojedinci mogli uključiti u interesnu problematiku.

Originalnost. Knjižnica Filozofskog fakulteta visokoškolska je knjižnica, a po opsegu svojega fonda druga je najveća knjižnica u Hrvatskoj, odmah iza Nacionalne i sveučilišne knjižnice u Zagrebu. Osim knjižne građe, posjeduje i kvalitetnu audiovizualnu zbirku te su važni programi koje provodi radi promicanja te zbirke. Originalnost programa Dokudah proizlazi iz želje i mogućnosti da poveže knjižničare, profesore, studente i vanjske suradnike nudeći raznovrsne sadržaje. Program je prilagodljiv i uklopiv, a da pritom zadržava svoju osnovnu ulogu i zadaću, a to je promicanje dokumentarnog filma. Opisivanjem faza nastanka i koncepta dan je model za oblikovanje srodnih programa.

Ključne riječi: aktivno građanstvo, audiovizualna zbirka, autorska prava, dokumentarni film, suradnja

\begin{abstract}
Purpose. The aim of this paper is to describe and explain the importance of Dokudah, a program implemented in the Library of the Faculty of Humanities and Social Sciences in Zagreb. The program consists of the projections of documentaries and discussions after the films. At the same time, the importance of documentary film, as a specific form of audiovisual material that is playing an increasingly important role in education, is explained. The program promotes documentary expression, collaboration, critical thinking and activism, pointing to the importance of audiovisual material and the AV collection in the Faculty Library. Also, it promotes audiovisual heritage and culture in general.
\end{abstract}

Approach. This paper will explain the theoretical and practical background of the program, its development and educational purpose. The acronym Dokudah means a 
„documentary break“, and it refers to the documentary film as a break in the library environment where books are in the majority, and thus it offers a pause from reading, but at the same time it educates and activates the students.

Findings. The program was created in 2015 and has been continually evolving. The results of the implemented program are the cooperation with the student clubs, then the cooperation with the independent production companies and getting licenses for screening of films, active viewing and chairing stimulating discussions, and finally the blog design and administration.

Research limitations. An important point in the Dokudah program is regulating copyright. In this sense, the whole Dokudah is based on cooperation, as the basic mode of performance and implementation of the program. The license for screening is obtained through the cooperation with the independent production companies, but under certain conditions. The program has continued to develop in accordance with the new copyright conditions in the Dokudah and Green Libraries program.

Practical implications. The Dokudah program highlights the important role of documentary film on all levels of education. The students can fill their free time between the lectures with such an additional program. Moreover, the program can also be included in lectures.

Social implications. By including documentary film as an additional program in the library, it is possible to actively engage the local community. In this sense, a blog was designed in order to help individuals find useful information at one place about the events.

Originality. The Library of the Faculty of Humanities and Social Sciences in Zagreb is the second largest library in Croatia. In addition to the books and journals, it possesses a high quality audiovisual collection and the programs that promote this collection are very important. The originality of this program comes from the desire of its founders to connect librarians, professors, students and external associates with the aim to create new content. The program can be further developed and adapted, while retaining its basic role and task, which is promoting documentary film. The description of stages of the creation and concept of the program in the paper can be used as a model for designing related programs in the future.

Keywords: documentary film, audiovisual collection, copyright, co-operation, active citizenship

\section{Uvod}

U Knjižnici Filozofskog fakulteta postoji potencijal u obliku iskoristivosti vizualnih medija i potreba za sadržajima koji bi aktivnije pratili filmsku djelatnost. Film je vizualni medij blizak današnjoj generaciji te istovremeno može informirati, educirati i pružiti estetski doživljaj. Vizualna građa ima tu karakteristiku da 
je koncentriranija i zbijenija te brža u izvedbi, za razliku od knjige, čije čitanje iziskuje izvjesno vrijeme. Bez obzira na dugotrajnije čitanje u odnosu na trajanje filma, dojmovi proizašli iz obaju izvora mogu potrajati čitav život. Vizualna građa ima moć u jednom trenu, štoviše, u jednom dahu izazvati snažnu emociju te stoga može poslužiti kao izvrstan edukativni i informativni materijal pomoću kojeg se može naglasiti pojedina tema i sadržaj.

$\mathrm{U}$ tom kontekstu nastala je ideja o projekcijama dokumentarnih filmova u Knjižnici Filozofskog fakulteta. Sam termin proizlazi iz akronima sintagme dokumentarni predah i odnosi se na dokumentarni film kao predah u okruženju u kojem prevladavaju knjige te se u tom smislu film javlja kao odmak od čitanja, no istovremeno educira, obrazuje i aktivira pojedince.

Program se provodi od 2015. godine s povremenim stankama i kontinuirano se nadograđuje.

\section{Nastanak programa}

Osim osnovnih i formalnih obrazovnih zadaća, visokoškolska knjižnica ima veliku ulogu u društvenoj i kulturnoj djelatnosti. Studenti Filozofskog fakulteta aktivni su društveni potencijal, a potičući ga dodatnim programima obogaćuje se i unapređuje kulturno i društveno okruženje.

Program Dokudaha namijenjen je zainteresiranim studentima, a među njima je i ciljana educirana publika koja uključuje studente filmoloških kolegija na Doktorskom studiju književnosti, izvedbenih umjetnosti, filma i kulture. Osim studentima, projekcijama mogu prisustvovati profesori, knjižničari i ostali zaposlenici Filozofskog fakulteta, a neke su varijante programa, kao Dokudah i zelene knjižnice, namijenjene svim zainteresiranim građanima.

\subsection{Audiovizualna građa u visokoškolskoj knjižnici}

Audiovizualna i multimedijska građa neprestano se mijenja i nadograđuje. Pod tim nazivom misli se na svu neknjižnu građu, tj. „dokumente za čije je korištenje potrebna oprema". ${ }^{1}$

Zakon o audiovizualnim djelatnostima navodi građu koja se podrazumijeva u audiovizualnoj zbirci, a to su

,,igrani i dokumentarni filmovi, animirani filmovi, eksperimentalni filmovi, multimedijski i transmedijski projekti, televizijske serije i filmovi, videoigre te sva druga audiovizualna djela koja su umjet-

1 Royan B.; M. Cremer. Smjernice za audiovizualnu i multimedijsku građu u knjižnicama i drugim ustanovama. Zagreb: Hrvatsko knjižničarsko društvo, 2005. [citirano: 2018-10-20]. Dostupno na: https://archive.ifla.org/VII/s35/pubs/avm-guidelines04-hr.pdf. 
nički i/ili autorski izraz bez obzira na tehnologiju kojom su nastala, podlogu na kojoj su fiksirana te način na koji se prikazuju.“2

Kao što se navodi u ovom zakonu, vidljivo je da audiovizualna građa obuhvaća raznoliku građu koja se mijenja s obzirom na tehnološke inovacije i izraze.

Najčešći mediji koji služe za pohranu audiovizualne građe jesu gramofonske ploče, audio- i videokasete, magnetni mediji, CD-i i DVD-i. Danas se od tih medija najviše koriste DVD-i jer su jednostavni za korištenje, mogu sadržavati različite podatke i imaju izvrsnu kvalitetu slike, a njihov fizički oblik omogućava skladištenje u velikim količinama. DVD-i se na tržištu nalaze od 1998. godine i brzo su ušli u široku primjenu. ${ }^{3}$ U Knjižnici Filozofskog fakulteta DVD-i se skladište u okomitom položaju u zatvorenim metalnim ormarima, koji su sigurniji od drvenih.

Istovremeno je građa na takvim medijima vrlo osjetljiva i ima ograničen vijek trajanja. Posebno ju treba zaštititi od vlage, mehaničkih oštećenja i toplinskih zraka, a osjetljiva je i na prašinu, hranu, piće i nečiste prste prilikom nepažljivog rukovanja. ${ }^{4}$ Ako tomu pribrojimo ubrzano mijenjanje tehnologije i zastarijevanje medija, jasna je opreznost u nabavi.

U Knjižnici Filozofskog fakulteta postoji audiovizualna zbirka koja posjeduje građu s različitih odsjeka objedinjenu u jedinstvenu zbirku. U zbirci se nalazi obimna zvučna, filmska, multimedijalna i elektronička građa različitih žanrova koja se većinom nabavlja prema narudžbi predmetnih knjižničara i u dogovoru s profesorima koji ju sve više koriste kao pomoćno sredstvo u nastavi. Osim toga, na fakultetu je nekoliko filmskih kolegija te im filmska građa služi kao dopuna nastavnom programu. S obzirom na raznolikost katedra na Filozofskom fakultetu, neki su filmovi teško nabavljivi i iznimno rijetki, što ovu zbirku čini posebno vrijednom. Osim igranih filmova, dio zbirke čine i dokumentarni filmovi koji su i fokus ovoga rada.

Audiovizualna zbirka u knjižnici pretpostavlja određeni dio tehničkih pomagala i opreme na kojoj se može reproducirati građa iz zbirke. Dio je opreme za reproduciranje audiovizualne građe iz Knjižnice Filozofskog fakulteta dislociran, što znači da se nalazi na pojedinim odsjecima i koristi se ovisno o njihovim nastavnim potrebama. Netko posjeduje projektor za dijapozitive, a netko kasetofon. Ta dislociranost olakšava skladištenje jer dodatna oprema ne zauzima prostor.

Nabavi audiovizualne građe pristupa se oprezno jer njezino posjedovanje uključuje i potrebu za opremom za reprodukciju, a uz to takva građa brzo zastarijeva i sklona je oštećenjima prilikom nestručnog ili nemarnog rukovanja. Oprez

2 Usp. Zakon o audiovizualnim djelatnostima: NN61/18. // Zakon.hr. Čl. 3. [citirano: 2018-1020]. Dostupno na: https://www.zakon.hr/z/489/Zakon-o-audiovizualnim-djelatnostima.

3 Lipovšćak, V. Zaštita audiozapisa. // Arhivski vjesnik 43 (2000), str. 131-132. [citirano: 201810-20]. Dostupno na: https://hrcak.srce.hr/index.php?id_clanak_jezik=16078\&show=clanak.

4 Royan B.; M. Cremer. Nav. dj., str. 14-15. 
u odabiru i nabavi opravdan je i razumljiv, no potreba za hibridnim izvorima informacija odraz je hibridnog vremena u kojem živimo i takva građa nije „luksuz, nego nužna komponenta jedinstvene knjižnične usluge“. ${ }^{5}$ Ako je moguće, neki bi oblik neknjižne građe trebao biti dio fonda visokoškolske knjižnice i svake druge knjižnice. Ako to nikako nije izvedivo, bilo bi dobro da postoje jasne upute gdje i kako se do takve građe može doći.

Za reproduciranje DVD-građe u Knjižnici Filozofskog fakulteta postoji pripadajuća mala audiovizualna dvorana s televizorom i DVD-uređajem. Dvorana ima svega sedam do deset mjesta i namijenjena je individualnim projekcijama ili manjim grupama studenata koji imaju zadatak pogledati neki film radi izvršavanja nastavnih obaveza. Potencijal male audiovizualne dvorane nije bio do kraja iskorišten, što je ukazivalo na potrebu osmišljavanja programa koji bi to promijenio te istovremeno promovirao audiovizualnu zbirku. Pojedine je prostore u knjižnici moguće iskoristiti višenamjenski, pritom imajući na umu osnovnu ulogu prostora. Tako neki prostori mogu postati izložbeni ili se uklopiti u različite programske koncepte.

\section{Izvođenje programa}

Osnovna programska koncepcija Dokudaha sastoji se od prikazivanja dokumentarnih filmova te diskusije nakon projekcije, usmjeravane prema zainteresiranosti gledatelja. S obzirom na to da nije bilo moguće financirati javna prikazivanja, kao prva sporna točka pojavljuje se kategorija autorskih prava.

\subsection{Autorska prava}

$\mathrm{Na}$ području intelektualnog vlasništva audiovizualne i multimedijske građe pravna su ograničenja stroga te postoji više nositelja autorskih prava. Neki su od nositelja prava autori, skladatelji, producenti, izvođači te distributeri i izdavačke kuće, pa je važno imati jasan uvid u pravne aspekte svih nositelja autorskih prava. ${ }^{6}$

Autorom filmskog djela smatraju se osobe koje su ga stvaralački i stilski uobličile i dale mu poseban karakter. Većinom se redatelj navodi kao najznačajniji autor, a ostali koautori su „scenarist, snimatelj, scenograf, kostimograf, masker, montažer, film. skladatelj, a prigodno i lokalno i ostali (koreograf, ton-majstor, majstor specijalnih efekata) “. ${ }^{7}$ Prema Zakonu o autorskom pravu i srodnim pravima koautorima audiovizualnog djela smatraju se glavni redatelj, autor scenarija,

5 Isto, str. 9.

6 Semenski, V. Autorstvo i pristupnice za audiovizualnu građu. // Vjesnik bibliotekara Hrvatske 59, 1/2(2016), str. 75. [citirano: 2018-10-20]. Dostupno na: https://hrcak.srce.hr/file/263060.

7 Filmski leksikon / urednici Bruno Kragić, Nikica Gilić. Zagreb : Leksikografski zavod Miroslav Krleža, 2003. [citirano: 2018-10-20]. Dostupno na: http://film.lzmk.hr/. 
autor dijaloga, glavni snimatelj, skladatelj glazbe za to djelo, a ako ima elemenata crteža, u tom slučaju i glavni crtač, odnosno glavni animator, pa je dozvoljena i mogućnost dokazivanja koautorstva drugim fizičkim osobama koje prema općim pravilima mogu biti koautori. ${ }^{8}$ Osobe poput kostimografa, scenografa, slikara maski, montažera i sl. smatraju se autorima doprinosa. ${ }^{9}$ Odnosi između filmskih producenata, koautora i autora doprinosa uređuju se ugovorom o audiovizualnoj produkciji i, ako nije drugačije određeno tim ugovorom, filmski producent stječe sva imovinska prava autora doprinosa. Koautori zadržavaju pravo na naknadu za iznajmljivanje audiovizualnog djela. ${ }^{10}$ Producent audiovizualnog djela je osoba koja pokreće i prati stvaranje projekta u svim fazama te brine o prikupljanju financijskih sredstava i preuzima odgovornost za sve stupnjeve u realizaciji projekta od početka do kraja. To uključuje početne faze poput izbora scenarija, preko osiguravanja financija i traženja sponzora, nadziranja kvalitete izvedbe, do promidžbe i konačnog plasiranja na festivale. ${ }^{11}$

Trajanje autorskog prava audiovizualne građe za koautorsko djelo računa se sedamdeset godina od smrti koautora koji je najdulje živio (glavni redatelj, autor scenarija, autor dijaloga, i skladatelj glazbe korištene za to djelo). ${ }^{12}$ Što se tiče producenta, on polaže pravo na reproduciranje, distribuiranje, iznajmljivanje, javno prikazivanje i stavljanje na raspolaganje javnosti i njegova prava traju 50 godina od prve fiksacije djela. ${ }^{13}$

Knjižnice definiraju svoj odnos prema audiovizualnoj građi na temelju ugovora sklopljenih s distributerima, a takvi ugovori dopuštaju samo privatnu posudbu knjižnične građe. ${ }^{14}$ Neovlaštena uporaba audiovizualne građe može se kazniti novčanom kaznom ili kaznom zatvora do tri godine ako je priopćenjem javnosti pribavljena imovinska korist ili ako se oštetio netko u lancu autorskih i koautorskih prava. ${ }^{15}$

\footnotetext{
8 Zakon o autorskom pravu i srodnim pravima: pročišćeni tekst zakona: NN 167/03, 79/07, 80/11, 125/11, 141/13, 127/14, 62/17. // Zakon.hr. Cl. 116. [ citirano: 2018-10-20]. Dostupno na: https://www.zakon.hr/z/106/Zakon-o-autorskom-pravu-i-srodnim-pravima.

9 Isto. $\breve{C l} .117$.

10 Isto. Čl. 118.

11 Martinis Filković, L. Biti (filmski) producent u Hrvatskoj. // Buro 24/7. [citirano: 2018-1020]. Dostupno na: http://www.buro247.hr/kultura/ekspert/biti-filmski-producent-u-hrvatskoj1. htmltica.

12 Zakon o autorskom pravu. Nav. dj., čl. 100.

13 Horvat, A.; D. Živković. Knjižnice i autorsko pravo. Zagreb: Hrvatska sveučilišna naklada, 2009. Str. 84.

14 Isto.

15 Kazneni zakon: pročišćeni tekst zakona: NN 125/11, 144/12, 56/15, 61/15, 101/17. // Zakon. hr. Čl. 285 [citirano: 2018-10-20]. Dostupno na: https://www.zakon.hr/z/98/Kazneni-zakon.
} 


\subsection{Suradnja i izvođenje programa}

U traganju za pravnim okvirom za održavanje programa Dokudaha nametnuo se koncept suradnje kao mogući model za provođenje programa. U početku, suradnja se ostvarila sa studentskim udrugama koje su djelovale na pojedinim odsjecima, poput udruga studenata indologije i studenata sociologije.

Sa studentskim udrugama dogovoreno je da će se organizirati projekcije dokumentarnih filmova usko vezanih uz nastavni sadržaj, potaknute interesom studenata. U tom početnom konceptu za prikazivanje filmova nije postojao uvjet da građa postoji u samoj knjižnici. Prvi prikazani film bio je India's Daughter i prikazan je u suradnji s Klubom studenata indologije Taraniginī. Film je iznimno dojmljiv i potaknuo je studente na razmjenu iskustva o boravku u Indiji, bilo kao dio studentskih programa ili vlastitim angažmanom.

Kao okvir za prikazivanje filmova, a da se pritom ne naruše autorska prava, poslužio je članak 88 Zakona o autorskom pravu i srodnim pravima:

„Dopušteno je javno izvođenje ili scensko prikazivanje autorskih djela u obliku izravnog poučavanja na nastavi, ili na priredbama koje su vezane uz nastavu, u opsegu opravdanom obrazovnom svrhom koja se želi postići takvim priopćavanjem, ako se autorsko djelo ne koristi radi ostvarivanja izravne ili neizravne imovinske ili komercijalne koristi za obrazovnu ustanovu, organizatora ili treće osobe, ako izvođači ne primaju naknadu za izvođenje autorskih djela, te ako se ne naplaćuju ulaznice. “16

Takav je koncept tražio dopunu jer nisu svi studentski klubovi, a ni svi studenti iz pojedinih klubova, zainteresirani za dokumentarni film te je to saznanje potaknulo promišljanje o drugim oblicima izvođenja programa. Svaki neformalno okupljeni broj studenata može se nazvati javnošću, a ona je definirana kao „veći broj osoba koje su izvan uobičajenoga užeg kruga osoba usko povezanih rodbinskim ili drugim osobnim vezama“. ${ }^{17}$ Kako bi se mogla ostvariti željena suradnja, osmišljeni su uvjeti koji se odnose na ograničenje prostora, ograničenje broja studenata i naglašavanje edukativne uloge programa. Studenti moraju najaviti svoj dolazak i obvezni su prisustvovati kratkoj diskusiji nakon projekcije.

Nakon nekoliko pokušaja uspostave suradnje s produkcijskim kućama, suradnja se ostvarila s nezavisnom dokumentarnom produkcijskom kućom Factum koja je pristala na unaprijed dogovorene uvjete i omogućila nam prikazivanje dokumentarnih filmova. Neki su filmovi starijih datuma te se ispostavilo da ponovna aktualizacija tih tema može biti korisna za autore, tj. redatelje i koautore, za produkcijsku kuću, studente te, konačno, za samu temu dokumentarnog filma. Tako

16 Zakon o autorskom pravu. Nav. dj., čl. 88.

17 Isto, čl. 3. 
su npr. prilikom gledanja filma BBB iz 1998. godine, čija je tema borba Bad Blue Boysa za povratak starog imena nogometnog kluba, studenti sociologije pronašli vrijednog gosta navijača, koji je iznijevši svoju navijačku viziju potaknuo zanimljivu diskusiju među ostalim sudionicima programa.

Intenzivan period promocije filmova traje oko godinu i pol do dvije godine te se većina tih filmova prikazivala na festivalima, u kinima ili na tematski povezanim događajima i nije ih se imalo prilike nigdje vidjeti ni pronaći. Neki filmovi koji su zatraženi nisu mogli biti odobreni jer autorska prava ne pripadaju samo produkcijskoj kući Factum, već se dijele s drugim distributerima te za takve filmove nije dobiveno odobrenje i stoga nisu prikazivani.

Prikazana su 23 filma iz produkcijske kuće Factum. Njihovi se filmovi tematski granaju u tri kruga ${ }^{18}$ iako se teme mogu prepletati i nadopunjavati. Program Dokudaha pokušao je zastupiti svaku temu.

Prva tema odnosi se na filmove iz hrvatske povijesti koja može provocirati i izazivati gledatelja, poput Goli, Djeca tranzicije ili gore spomenuti film BBB. Na primjeru filma Goli u diskusiji nakon projekcije imali smo priliku vidjeti nekoliko različitih pristupa dokumentarnom filmu. Polazeći od potpuno različitih očekivanja gledatelja o tome što žele saznati, film je ostavio potpuno različite dojmove, a konačni doživljaji gledatelja su obogaćeni nakon što su ostali dojmovi osviješteni.

Drugoj temi pripadaju autobiografski intimni dokumentarni filmovi poput Dečko kojem se žurilo, Sve o Evi ili filma Čedo na čijoj su se projekciji gledatelji iznenadili suprotnostima koje su izazvali vizualni, atmosferični kadrovi pojačani glazbom i sirova tema beskućništva.

Treća tema pokriva dokumentarce o ljudima s margine poput Pula, heroin, Zajedno, ili Peščenopolis, na čijim smo projekcijama uspjeli saznati kako pojedinci gledaju na ovisnosti, marginalne grupe ili npr. u filmu Peščenopolis usporediti prošlost i sadašnjost života u zagrebačkom kvartu Peščenica.

Na programu Dokudaha prikazivanju filmova prisustvuje pet do sedam ljudi. S obzirom na to da mala audiovizualna dvorana može primiti svega desetak ljudi, to je dovoljan broj za tu prostoriju. Grupa nije velika, no diskusija vođena nakon filma može ostvariti značajne i vrijedne uvide jer svaki pojedinac ima važnu ulogu te može činiti značajnu razliku. Ono što bi ojačalo grupu i sadržajno ju unaprijedilo jest kontinuirana povezanost. Na toj primisli izgradila se buduća vizija Dokukluba, tj. dokumentarnog kluba po uzoru na književne klubove.

Slijedom događaja uspostavljena je i suradnja s Fade inom, produkcijskom kućom ,usmjerenom prema filmskoj i video produkciji angažiranog sadržaja“. ${ }^{19}$ Taj društveni moment važan je u konceptu čitavog programa, tako da će u ovom

\footnotetext{
18 Factum documentary film project. [citirano: 2018-10-20]. Dostupno na: http://factum.com.hr/ hr/factum/o_nama.

19 Fade in. [citirano: 2018-10-20]. Dostupno na: http://www.fadein.hr/.
} 
razdoblju suradnje s Fade inom biti naglašena povezanost s temama iz okoline. Većina je filmova koji će se pogledati u suradnji s njima već postavljena na online videoservise. To je dobar način približavanja dokumentarnog filma gledateljima i njegove promocije. Tako je i produkcijska kuća Factum pokrenula novi projekt Factum Online pod nazivom Video na zahtjev. Za javnost su dostupni neki recentni filmovi, ali i neki filmovi starijih datuma čije se teme ponovno lako aktualiziraju.

Postavlja se pitanje zašto bi netko bio zainteresiran za gledanje filmova u organiziranim uvjetima ako to isto može napraviti sjedeći kod kuće. Današnje globalno društvo i sveopća umreženost daju privid povezanosti, no zbog kontinuiranog izostanka kontakta pojedinci ostaju zakinuti za dijalog koji je ključan za razvoj misli i naviranje ideja. Dovoljna je pripadnost manjoj grupi kako bi se potaknula svijest i aktivnost o društvu i ulozi pojedinca u tom društvu. Dokumentarni filmovi aktualizirajući situacije u bližoj okolini potiču kritičko promišljanje društvene zbilje. Diskusije nakon filma uz razmjenu dojmova ključni su trenutak interakcije vizualnog medija, izložene teme i svih sudionika.

\section{Uloga i cilj izvođenja programa}

Program Dokudaha ima ulogu promicanja dokumentarnog filma i stvaranja kompetentnih i aktivnih građana. Osim zainteresiranih studenata na Filozofskom fakultetu, postoji i educirana publika koja uključuje studente filmoloških kolegija na Doktorskom studiju književnosti, izvedbenih umjetnosti, filma i kulture i takav bi program mogao biti izvrsna nadopuna studija. Projekcijama mogu prisustvovati i ostali zainteresirani pojedinci s obzirom na to da je Knjižnica Filozofskog fakulteta otvorena za sve. Vanjski korisnici ne mogu se učlaniti u knjižnicu ni posuđivati građu, ali unutar knjižnice mogu se koristiti svom građom i sudjelovati u većini događaja. Obrazovanje dostupno svima ideja je koja najbolje dočarava misiju i viziju knjižnice. U tom smislu preko programa Dokudaha želi se ponuditi dodatni edukativni i obrazovni sadržaj.

\subsection{Dokumentarni film}

Dokumentarni film u Hrvatskoj njeguje dugu tradiciju te se u odnosu na klasičan film može snimiti s drastično nižim budžetom i poslužiti kao eksperiment, učenje ili uvod u neku širu temu. Budući da pretendira na stvarnost, autentičan je i blizak ljudima. Bilježenje okoline i ,zadubljivanje u okoliš može prerasti u reportažu, pa u složeni dokument, u svjedočenje o životu i povijesti, može nadrasti skup pukih podataka i biti i umjetnički nadahnuto djelo“. ${ }^{20}$ Prve su snimke zabilježene

20 Peterlić, A. Hrvatski dokumentarni film. // ZAPIS: bilten Hrvatskog filmskog saveza 43(2003). [citirano: 2018-10-20]. Dostupno i na http://www.hfs.hr/nakladnistvo_zapis_detail.aspx?sif_clanci=393\#.XDMhtVVKjct. 
početkom 20. stoljeća, a 30-ih se godina potiče veći razvoj dokumentarnog filma djelovanjem Škole narodnog zdravlja u Zagrebu čija djelatnost uključuje i dokumentarizam te svjedoči o ljepotama Hrvatske i životu u njoj. Početna bilježenja prerastaju u obrazovne filmove iz povijesti i umjetnosti. Nakon Drugog svjetskog rata najprije su se snimali programski i propagandni filmovi koji ističu kolektivizam kao odraz društvenih uređenja, ali ubrzo fokus prelazi na pojedince i poetičnije teme. Tijekom 60 -ih javljaju se teme s kritičkim osvrtom na društvo, govoreći o životu i običajima malog naroda i njegovih pojedinaca. Taj period bilježi iznimna ostvarenja redatelja poput Kreše Golika, Krste Papića i ostalih. Od sedamdesetih do devedesetih godina interes za dokumentarni film slabi, no ponovno se aktualizirao devedesetih u ratnim temama, kad građanstvo postaje svjesno važnosti dokumentarizma. ${ }^{21}$ Od tog razdoblja utjecaj dokumentarnog filma raste, za što su, osim Hrvatskog filmskog saveza, najzaslužnije nezavisne produkcijske kuće.

Dokumentarni je film važan izvor informacija, a istovremeno je i umjetnost sam za sebe. Činjenice su glavna razlika između dokumentarnog i igranog filma jer kreiraju naš stav prema prikazanoj temi i daju nam određenu novost unutar nje. Kao sredstvom priopćavanja njime su se prenosile obavijesti iz različitih područja ljudske djelatnosti. ${ }^{22}$ Takva vrsta filma može poslužiti u svim krugovima javnosti kao važno obrazovno, edukacijsko, informacijsko, ali s druge strane i propagandno sredstvo čija je namjera dati određenu informaciju koja nije nužno objektivna.

Gledatelj pristupa dokumentarnom filmu s očekivanjima koja sugeriraju određeni stav prema filmu. Kao ključne značajke takvog filma navode se „činjeničnost, novina i izlagačka sustavnost ${ }^{\text {". }}{ }^{23}$ Informiranost o činjenicama daje gledatelju informaciju i novi uvid u temu koji nije čisti umjetnički doživljaj, nego iziskuje kontekst. Veliku ulogu ima izlagačka sustavnost, tj. montaža snimljenog materijala jer količina grubo snimljenog materijala počinje dobivati konačno oblikovanje i daje intonaciju te uobličuje priču prema redateljevoj ideji, viziji ili scenariju. ${ }^{24}$ Važni elementi filma mogu se razmatrati na tri razine. Prvoj pripadaju glavni akteri, naturščici sa svojim neobičnim pričama s običnim detaljima ili običnim pričama s neobičnim detaljima, druga razina obuhvaća rabljene stilističke konvencije, a treća razina obuhvaća javnu interpretaciju filma. ${ }^{25}$ Međusobno korelirajući, svi elementi filma potiču aktivno gledanje.

\footnotetext{
21 Isto.

22 Turković, H. Razumijevanje filma: ogledi iz teorije filma. Zagreb: Grafički zavod Hrvatske: Akademija dramske umjetnosti, 1988.

23 Isto, str. 69-70.

24 Isto.

25 Nisbet, M. C.; P. Aufderheide. Documentary film: towards a research agenda on forms, functions, and impacts. // Mass Communication and Society 12(2009), str. 451. DOI: https://doi. org/10.1080/15205430903276863.
} 


\subsection{Aktivno gledanje}

Teme dokumentarnih filmova mogu educirati, informirati, inspirirati, izazivati i provocirati gledatelje. Sve su aktualniji filmski festivali koji promoviraju dokumentarni film okupljajući sudionike kako bi svjedočili o lokalnim i globalnim pričama, sudjelovali u dijalogu i često revidirali svoje stavove i gledišta o različitim pitanjima. Aktivno gledanje uključuje promišljanje i propitkivanje, što potiče želju za reakcijom i djelovanjem te to vodi prema uključivanju. ${ }^{26}$ Trenutak u kojem se stvara osjećaj da se nešto može učiniti i da pojedinac čini razliku može aktivno utjecati na život studenata, a aktivni i kompetentni studenti preduvjet su aktivnom građanskom društvu. Kompetentna osoba može nešto poduzeti i zna kako to poduzeti, a da pritom koristi svoje stečeno znanje i vještine „,ne zato što mora ili zato što joj to donosi puku materijalnu korist, nego zato što vjeruje da je takvo djelovanje ispravno i dobro za nju, posao koji obavlja i zajednicu u kojoj živi““. ${ }^{27}$ Ono što je važno naglasiti kod kompetentne osobe jest da se kontinuirano nadograđuje, uči i informira jer se njezina učinkovitost mijenja sa situacijom i uvjetima te se vještine i znanja moraju stalno nadopunjavati i prilagođavati kako bi rješenje bilo moralno ispravno i kako bi unaprijedilo pojedinca i zajednicu. ${ }^{28}$ Suvremeno demokratsko društvo treba kompetentnog građanina, a dokumentarni filmovi mogu djelovati kao promicatelji solidarnosti između studentske i lokalne zajednice.

Ne smije se zanemariti ni umjetnička strana dokumentarnog filma i njegova vizualna moć. Doživljaj vizualnosti jači je jer ima uporište u stvarnosti, čime se djeluje na percepciju gledatelja sugerirajući intenzivnije doživljaje. Tako empatija u umjetničkom oblikovanju dokumentarnog filma može imati spiritualni učinak, ostavljajući jači dojam jer umjetnost graniči i sa stvarnošću, a ne samo s fikcijom. ${ }^{29}$ Iako dokumentarni film pretendira na stvarnost, on nije stvarnost sam po sebi. Isto tako, varijante tumačenja imaju mnogo inačica. Izlaganje različitih inačica donosi nove uvide, koji ponovno mogu utjecati na pojedinčeve stavove i mišljenja te ih kontinuirano nadograđivati, dopunjujući cjeloživotni proces učenja.

$\mathrm{U}$ tom tonu osmišljen je i blog Dokudaha. ${ }^{30} \mathrm{U}$ blogu se želi iskoristiti potencijal informativne uloge dokumentarnog filma. Trenutno se na blogu nalazi petna-

26 Roy, C.; S. Young. Reflecting on the screen: documentary film festivals and citizenship education. // Adult Education Research Conference. [citirano: 2018-10-20]. Dostupno na: http:// newprairiepress.org $/$ cgi $/$ viewcontent.cgi article $=3729 \&$ context $=$ aerc.

27 Agencija za odgoj i obrazovanje. Kurikulum građanskog odgoja i obrazovanja. 2012. Str. 4. [citirano: 2018-10-20]. Dostupno na: https://www.azoo.hr/images/Kurikulum_gradanskog_odgoja_i_obrazovanja.pdf.

28 Isto.

29 Patel, S.; M. Wallis-Redworth; S. Jackson; L. Rose. Art and science: promoting understanding and empathy through film. // British Journal of Midwifery 25, 11(2017),734-740. DOI: http:// dx.doi.org/10.12968/bjom.2017.25.11.734.

30 Dokudah: dokumentarni predah. [citirano: 2018-10-20]. Dostupno na: https://Dokudah. wordpress.com/. 
est tekstova. Blog može poslužiti kao najava filma, no nisu svi prikazani filmovi popraćeni tekstom. Osim toga, uloga je bloga da tekstovi opisuju i promoviraju filmove koji postoje u audiovizualnoj zbirci u knjižnici i mogu se posuditi. Tako su npr. predstavljeni filmovi Sve je bijelo u Barkingu ${ }^{31}$ ili Darwinova noćna mora $^{32}$, dokumentarni film koji je dio vrijedne zbirke Austrijske knjižnice Zagreb (Österreich-Bibliothek Zagreb). Sadržaj tekstova na blogu sastoji se od dva dijela. Prvi dio čini kratki osvrt na filmove, a drugi dio, naslovljen Gledaj: akcija, ima ulogu okupiti glavne informacije, adrese i linkove vezane uz dokumentarni film koji bi mogli pomoći pojedincima da se aktivnije uključe u zajednicu ili da se informiraju ako sami traže pomoć.

U takvo aktivno gledanje dobro su se uklopili i filmovi ekoloških tema čija je namjera da potaknu društvo na promišljanje o okolišu i utjecaju ljudi na sveopću devastaciju i potrebu očuvanja planeta Zemlje. Svake se godine u organizaciji aktivističke grupe Zelena akcija održava filmski festival na kojem se prikazuju dokumentarni filmovi vezani uz ekološke teme. Mreža zelenih knjižnica djeluje na nacionalnoj razini te je dobila odobrenje za prikazivanje tih filmova. S obzirom na to da se Knjižnica Filozofskog fakulteta uključila u Mrežu zelenih knjižnica, program Dokudaha koristi filmove iz njihovih programa. Na taj način program se preselio u Konferencijsku dvoranu koja na raspolaganju ima 90 mjesta. Neki su dokumentarni filmovi prikazani u sklopu obilježavanja određenih dana važnih za promicanje ekoloških vrijednosti.

Utjecaj dokumentarnog filma na pojedinca i društvo iznimno je velik te treba koristiti i razvijati te mogućnosti. U kontekstu ekoloških tema, društvo i pojedinac moraju se zalagati za zaštitu prirode, zaštitu voda, šuma, tla, recikliranje sirovina, energetsku učinkovitost, korištenje obnovljivih izvora energije i slično.

\section{Mogućnosti programa}

Potencijal i iskoristivost dokumentarnog filma u visokoškolskoj knjižnici veliki su i sadržajno vrlo raznoliki. Takav sadržaj podnosi različite motivacije zbog kojih gledatelji prisustvuju programu. Neki traže zabavu, nekima su važne informacije, neki su otvoreni za mijenjanje svojih stavova, neki traže moguće puteve djelovanja te se potencijalno mogu uključiti u lokalne i globalne aktivnosti. ${ }^{33}$

Važno je da se program provodi i dalje, mijenjajući se i nadograđujući prema potrebi, situaciji ili zahtjevima studenata. Ono na što se treba usredotočiti u ovoj fazi, odnosno prvi fokus programa, jest uklapanje programa u nastavu i ispitivanje

31 Sve je bijelo u Barkingu. [citirano: 2018-10-20]. Dostupno na: https://dokudah.wordpress. com/2018/10/02/sve-je-bijelo-u-barkingu-all-white-in-barking-2007/.

32 Darwinova noćna mora. [citirano: 2018-10-20]. Dostupno na: https://dokudah.wordpress. com/2017/11/02/darwinova-nocna-mora-2004/.

33 Roy, C.; S. Young. Nav. dj., str. 433. 
koliko se u samoj nastavi na visokoškolskoj razini koristi dokumentarni film. Prema procjenama, većina profesora koristi ga barem jednom semestralno i postoji mogućnost da se takav sat održi u većem prostoru u kojem je moguće okupiti veći dio zainteresirane publike, što bi utjecalo na širi domet dokumentarnog filma i teme, a samim time i na širi utjecaj na zajednicu. Drugi je fokus okupljanje studenata zainteresiranih za dokumentarni film i zajedničko daljnje razvijanje programa. Isto tako, poželjna je i aktivnija suradnja s nezavisnim produkcijama od kojih se može naučiti praktični dio produkcije, režiranja, promocije i ostalih vidova nastanka dokumentarnog filma.

\subsection{Otvorena nastava}

Kako bi se povezao knjižnični program s nastavnim planom i programom, što bi rezultiralo kvalitetnijim pristupom nastavi i aktivnostima među profesorima, studentima i knjižničnim osobljem, Dokudah se lako može uklopiti u koncept otvorene nastave. U tom kontekstu intenzivirana je suradnja s profesorima Filozofskog fakulteta.

I na nižim razinama obrazovanja nastavni se planovi i programi mijenjaju iz forme isključivo frontalnog obrazovanja, znanstveno-disciplinarne kontrole sadržaja i faktografskog znanja u formu zajedničkog, integriranog i interdisciplinarnog planiranja sadržaja učenja radi pripremanja učenika za kompetentan i aktivan život. ${ }^{34}$

Kao dodatni nastavni alat, dokumentarni film ima značajno mjesto i mnogi ga profesori koriste kako bi pojačali nastavu ili pojedinačnu temu svog predavanja ili izlaganja. U nastavu povijesti može se dobro uklopiti i pokazalo se da ga studenti doživljavaju kao točan i pouzdan izvor znanja o prošlosti, što može biti pozitivno, ali i problematično jer često izostaje kritički pristup izvoru koji je nužan da bi se objektivno pristupilo temi. ${ }^{35}$

Filmovi pogledani u sklopu Dokudaha većinom su bili hrvatske proizvodnje, a samim time odraz su društvene situacije u Hrvatskoj i teme se mogu iskoristiti za analizu različitih perspektiva i stavova. Propitkujući interese koji se nameću, studenti mogu proširiti uvide i svoje mišljenje objektivizirati kako bi postali građani koji kritički promatraju okolinu i reagiraju na nepravednosti koje se događaju. Isto tako, studenti se trebaju senzibilizirati za probleme osjetljivijih skupina društva. Kako bi se studenti uključili u društveni život i postali aktivni građani, važno je njegovanje triju ciljeva. To su objektivna prosudba, proširen pogled na

34 Kurikulum. Nav. dj., str. 4.

35 Marcus, A. S.; J. D. Stoddard. The inconvenient truth about teaching history with documentary film: strategies for presenting multiple perspectives and teaching controversial issues. // The Social Studies 100, 6(2009), str. 280. DOI: https://doi.org/10.1080/00377990903283957. 
čovječanstvo i promišljanje o općem dobru, a dokumentarni film može promicati sve navedeno. ${ }^{36}$

\subsection{Klub ljubitelja dokumentarnog filma}

Zbog ograničenog vremena koje nameću predavanja i obaveze vezane uz primarne kolegije, uključivanje studenata u dodatne sadržaje biva otežano. Kako bi studenti prisustvovali dodatnim programima u knjižnici, oni moraju biti dovoljno interesantni da ih privuku ili korisni i primjenjivi da zadrže sudionike. Usto, važan je čimbenik i vrijeme. Iz tog razloga planira se osnivanje Dokukluba, grupe osmišljene po uzoru na književne klubove, koja bi aktivnije pristupila daljnjem razvoju programa. Pripadnost grupi stvorila bi svojevrsnu neformalnu lojalnost te bi program mogao napredovati na iduću razinu.

U usvajanju gradiva u obrazovnom sustavu veliku važnost imaju ishodi, u formi iskaza o očekivanim postignućima učenika. ${ }^{37} \mathrm{U}$ ovom kontekstu izbornog, dodatnog, nenastavničkog programa obrazovni ishodi mogu se primijeniti na studente. Gledanje dokumentarnih filmova može pridonijeti upoznavanju sebe, otkrivanju vlastitih interesa, ali i vlastitih ograničenja. Budući da su gledatelji interaktivna grupa, konačno će mišljenje biti rezultat suradnje te ,interaktivnog i kumulativnog procesa, (...) ali i nadmetanje određeno zajedničkim pravilimaa ${ }^{\text {(38 }}$ koje potiče diskusiju, dokazivanje i asertivnost u okviru poštivanja tuđih stavova i mišljenja.

Takvom suradnjom sa studentima moglo bi se oplemeniti, obogatiti i učiniti program interaktivnijim i korisnijim.

\section{Zaključak}

Program Dokudaha važan je edukativni sadržaj u Knjižnici Filozofskog fakulteta i njegovo provođenje igra aktivnu ulogu u edukaciji i senzibilizaciji studenata. Željeni je cilj promicanje dokumentarnog izričaja, razvijanje kritičkog mišljenja i, samim time, poticanje aktivizma u društvu, uklapanje projekcija u programsku nastavu te, u konačnici, prepoznavanje važnosti audiovizualne građe i njezine zbirke u Knjižnici Filozofskog fakulteta te audiovizualne baštine i kulture općenito. Tijekom tri godine prikazivanja studenti su imali priliku promisliti o temama koje ih nekim djelom dotiču u svakodnevnom životu i na taj način pokazati inicijativu u društvu, sukladno svojim interesima.

\footnotetext{
36 Isto, str. 281.

37 Kurikulum. Nav. dj., str. 5.

38 Isto.
} 
Uključivanje dokumentarnog filma kao dodatnog programa u ponudu knjižničnih događanja obogaćuje program za vrlo vrijedan vizualni sadržaj koji, osim ponuđenog estetskog doživljaja, često proširuje svoju ulogu.

\section{LITERATURA}

Agencija za odgoj i obrazovanje. Kurikulum građanskog odgoja i obrazovanja. 2012. [citirano: 2018-10-20]. Dostupno na: https://www.azoo.hr/images/Kurikulum_gradanskog_odgoja_i_obrazovanja.pdf.

Dokudah: dokumentarni predah. [citirano: 2018-10-20]. Dostupno na: https://Dokudah. wordpress.com/.

Factum documentary film project. [citirano: 2018-10-20]. Dostupno na: http://factum. com.hr/hr/factum/o_nama.

Fade in. [citirano: 2018-10-20]. Dostupno na: http://www.fadein.hr/.

Filmski leksikon / urednici Bruno Kragić, Nikica Gilić. Zagreb: Leksikografski zavod Miroslav Krleža, 2003. [citirano: 2018-10-20]. Dostupno na: http://film.lzmk.hr/.

Horvat, A.; D. Živković. Knjižnice i autorsko pravo. Zagreb: Hrvatska sveučilišna naklada, 2009.

Kazneni zakon: pročišćeni tekst zakona: NN 125/11, 144/12, 56/15, 61/15, 101/17. // Zakon.hr. [citirano: 2018-10-20]. Dostupno na: https://www.zakon.hr/z/98/Kazneni-zakon.

Lipovšćak, V. Zaštita audiozapisa. // Arhivski vjesnik 43 (2000), 109-136. [citirano: 2018-10-20]. Dostupno na: https://hrcak.srce.hr/index.php?id_clanak_jezik $=16078 \&$ show $=$ clanak.

Marcus, A. S.; J. D. Stoddard. The inconvenient truth about teaching history with documentary film: strategies for presenting multiple perspectives and teaching controversial issues. // The Social Studies 100, 6(2009), 279-284 DOI: https://doi. org/10.1080/00377990903283957.

Martinis Filković, L. Biti (filmski) producent u Hrvatskoj. // Buro 24/7. [citirano: 201810-20]. Dostupno na: http://www.buro247.hr/kultura/ekspert/biti-filmski-producent-u-hrvatskoj1.htmltica.

Nisbet, M. C.; P. Aufderheide. Documentary film: towards a research agenda on forms, functions, and impacts. // Mass Communication and Society 12(2009), 450-456. DOI: https://doi.org/10.1080/15205430903276863.

Patel, S.; M. Wallis-Redworth; S. Jackson; L. Rose. Art and science: promoting understanding and empathy through film. // British Journal of Midwifery 25, 11(2017),734740. DOI http://dx.doi.org/10.12968/bjom.2017.25.11.734. 
Peterlić, A. Hrvatski dokumentarni film. // ZAPIS: bilten Hrvatskog filmskog saveza 43(2003). [citirano: 2018-10-20]. Dostupno i na http://www.hfs.hr/nakladnistvo_zapis_detail.aspx?sif_clanci=393\#.XDMhtVVKjct.

Roy, C.; S. Young. Reflecting on the screen: documentary film festivals and citizenship education. // Adult Education Research Conference. [citirano: 2018-10-20]. Dostupno na: http://newprairiepress.org/cgi/viewcontent.cgi?article=3729\&context $=$ aerc.

Royan B.; M. Cremer. Smjernice za audiovizualnu i multimedijsku građu u knjižnicama i drugim ustanovama. Zagreb: Hrvatsko knjižničarsko društvo, 2005. [citirano: 201810-20]. Dostupno na: https://archive.ifla.org/VII/s35/pubs/avm-guidelines04-hr.pdf.

Semenski, V. Autorstvo i pristupnice za audiovizualnu građu. // Vjesnik bibliotekara Hrvatske 59, 1/2(2016), 73-99. [citirano: 2018-10-20]. Dostupno na: https:/hrcak. srce.hr/file/263060.

Turković, H. Razumijevanje filma: ogledi iz teorije filma. Zagreb: Grafički zavod Hrvatske: Akademija dramske umjetnosti, 1988.

Zakon o audiovizualnim djelatnostima: NN61/18. // Zakon.hr. [citirano: 2018-10-20]. Dostupno na: https://www.zakon.hr/z/489/Zakon-o-audiovizualnim-djelatnostima.

Zakon o autorskom pravu i srodnim pravima: pročišćeni tekst zakona: NN 167/03, 79/07, 80/11, 125/11, 141/13, 127/14, 62/17. // Zakon.hr. [ citirano: 2018-10-20]. Dostupno na: https://www.zakon.hr/z/106/Zakon-o-autorskom-pravu-i-srodnim-pravima. 
